\title{
Operationalizing Cultural Autonomy in International Law as a Form of Effective Participation in Decision-Making
}

\author{
János Fiala-Butora \\ Hungarian Academy of Sciences, Budapest, Hungary \\ NUI Galway, Galway, Ireland
}

\begin{abstract}
According to most commentators, cultural autonomy is not a right recognized by positive international law. This article argues that the core elements of cultural autonomy can be derived from the right to effective participation guaranteed by Article 15 of the Framework Convention on the Protection of National Minorities (FCNM). The existing standards developed by the Advisory Committee on the Framework Convention are rather vague, and fail to regulate several issues important for effective participation. This is not determined by the wording of the Convention, but by the Committee's choice to provide states with a very wide margin of appreciation. To fill in the gaps in the Committee's jurisprudence, the article examines the case study of a recently adopted law on support for minority cultures in Slovakia. By using a qualitative-substantive approach, it specifies the content of cultural autonomy by defining its purpose, as well as the conditions under which it can be achieved. Applying the Committee's general criteria to the specific problems raised by the Slovak law, the article establishes the core positive law requirements vis-à-vis the right to cultural autonomy. In closing, the article argues that the Committee should adopt detailed standards, similar to those proposed in the text, in order to enforce the right to effective participation in practice. Operationalizing effective participation leads in substance to the enforcement of the right to cultural autonomy, which is a developed form of the former.
\end{abstract}

Keywords: national minorities, minority rights, minority culture, cultural autonomy, right to participate in public affairs, Framework Convention for the Protection of National Minorities (FCNM)

\section{Introduction}

Cultural autonomy is an important aspiration of minority communities. Many recognize it as a good solution for preservation and development of minority cultures. ${ }^{1}$ However, according to most commentators, it is not a right recognized by positive international law (Dinstein, 2011; Shaw, 1997). Scholarly works on cultural autonomy are either descriptive, analysing cultural autonomy schemes adopted in specific states; or normative, developing criteria which a certain approach must fulfil in order to be considered cultural autonomy (Hannum, 1990; Lapidoth, 1997; Suksi, 1998; Ghai, 2000; Tkacik, 2008). They share a central question

János Fiala-Butora, LL.M., S.J.D., research fellow, Institute for Legal Studies, Centre for Social Sciences, Hungarian Academy of Sciences, Budapest, Hungary; lecturer, NUI Galway, Galway, Ireland.

${ }^{1}$ Positive experiences of autonomous regions as a source of inspiration for conflict resolution in Europe, Council of Europe Parliamentary Assembly Recommendation 1609 (2003), 24 June 2003; commentary on the effective participation of persons belonging to national minorities, Advisory Committee on the Framework Convention for the Protection of National Minorities, adopted on 27 February 2008, ACFC/31DOC(2008)001, para. 6. 
defining their analysis: Is there cultural autonomy in a certain state? And if there is, what does it look like?

This article adopts a different approach. It addresses a different question: What features make cultural autonomy an effective solution to specific problems of minority communities' cultural reproduction? The goal of the analysis is not to establish the existence of cultural autonomy in a certain country, but the general criteria by which its quality can be assessed. Any country can claim to have cultural autonomy by simply formally declaring any power-sharing mechanism to embody such autonomy. However, granting some minority representatives a degree of decision-making or consultative powers should not be sufficient to meet the substantive standards of autonomy. Qualitative criteria are needed to decide whether the approach is an effective one, or only autonomy in name and form.

A central argument of this article is that the core elements of cultural autonomy already exist in international law. They can be found in the requirements relating to the right of minorities to participate in decisions affecting their cultural life (Weller, 2004, 2010; Palermo, 2010; Verstichel, 2009). If the right to participate is taken seriously, its end result, effective participation, will be a form of cultural autonomy. In turn, cultural autonomy is only valuable, if it leads to effective participation in decision-making. The article will therefore assess the relevant articles of the Council of Europe's Framework Convention for the Protection of National Minorities (FCNM), in order to establish the core positive law requirements in relation to the right to participate in decision-making. These core standards will be applied to a case study of Slovakia, a country which has recently adopted a law on the support for minority cultures. Contrasting the new law and the debate surrounding its adoption with the approach of the Advisory Committee on the Framework Convention highlights further requirements which any effective cultural autonomy must fulfil.

The aim of the article is threefold. Its main goal is to establish the in-depth criteria which an effective cultural autonomy scheme must meet. Second, it assesses whether these criteria are already part of positive international law, and whether they can and should be part of it. Lastly, it also provides an assessment of the Slovak law on the support of minority cultures, to establish in what ways it meets the criteria and where it does not.

\section{The Object of the Analysis and the Methodology}

This article is concerned with concepts, such as cultural autonomy, financing of minority cultures, and effective participation in decision-making. For the purposes of the analysis, it is important to define these terms and their relationship.

Scholars define cultural autonomy differently, depending on the forms of autonomy they distinguish. The approach taken in this article is informed by the 2008 special edition of the International Journal of Minority and Group Rights on characterizations of the forms of autonomy, and rests on differentiating cultural autonomy from other related concepts (Légaré \& Suksi, 2008).

Personal autonomy can be defined as members of minority communities engaging in common activities in order to promote their culture by using essentially private law forms of organization (Suksi, 2008). By establishing associations and other forms of cooperation, they can achieve many of their goals without enjoying any special rights granted to them on the basis of their community membership (Légaré \& Suksi, 2008). This highlights the key difference between personal and cultural autonomy. The latter involves some public law recognition of minority communities, and grants decision-making and other powers to individuals based on membership in a culturally defined community (Tkacik, 2008). Personal autonomy is symmetrical; all citizens 
of the state enjoy formally the same rights to associate, regardless of their ethnic or cultural affinity. Cultural autonomy is asymmetrical: Members of minority communities enjoy different rights vis-à-vis the members of the majority. ${ }^{2}$

Territorial autonomy is also asymmetrical, but its key defining feature is not power based on community membership. Rather it is power based on political control of certain minority-populated territories. While cultural autonomy results in personal jurisdiction in relation to members of the community, territorial autonomy results in the community's political control over all residents of the autonomous territory, including residents belonging to other communities. The latter allows for a wider scope of powers which can be effectively exercised only on a territorial basis, such as general law-making powers in economic, social, and other policy areas, besides cultural and linguistic matters.

Cultural autonomy can be characterised as distinct from the above two concepts. It will be understood in a general sense as a right of members of a culturally defined minority community to govern themselves in matters relating to their culture (Yupsanis, 2016). It thus involves decision-making by members of the community over matters of culture, language, education, and other forms of cultural expressions specific to the community (Torode, 2008).

For the purposes of this article, the scope of cultural autonomy will be defined more narrowly. The analysis will follow the case study of the Slovak law on financing minority cultures, and assesses only decision-making related to cultural activities. Matters related to minority educational policy will not form part of the analysis, as they are not covered by the domestic law. Similarly, the rules on linguistic rights are governed by general legislation and with small exceptions the bodies of cultural autonomy have no powers in this area.

What remains within the scope of the analysis is decision-making in all matters related to culture that are not governed by general laws. This mainly means allocating financial support for the cultural activities of minorities, including support for the arts, publications, media, and scientific institutions. In a more general sense, the newly established cultural autonomy scheme allows minority representatives to make decisions about their cultural policy: Which areas of culture should be developed? What activities should receive priority over others? What cultural institutions should be established? And which should cease to operate?

Due to its narrow scope, it is arguable whether the Slovak system can even be analysed as a form of cultural autonomy. Palermo (2010) defined the term narrowly and argued that only one European country, Hungary, has such a system in place. Others understand the concept in a wider sense and accept as cultural autonomies systems with a much narrower scope and limited powers (Yupsanis, 2016; Torode, 2008). Petöcz (2010) considered the Slovak system "almost ... a kind of self-administration in cultural matters" (p. 752). Notwithstanding the debates over formal classification, the label of cultural autonomy is not decisive for the analysis. Neither the Slovak legislation, nor the analysed international norms use this term. They are concerned with participation of minorities in decision-making in the area of culture. The scope of these norms nevertheless overlaps with cultural autonomy as defined above.

The argument of this article is that ensuring effective participation in decision-making also ensures cultural autonomy. In other words, cultural autonomy is a form of effective participation in decision-making

\footnotetext{
${ }^{2}$ Not necessarily more rights, as whatever right is granted to minority communities through cultural autonomy, members of the majority are likely to enjoy the same right through a different, mainstream mechanism. The key is that majorities and minorities exercise these rights differently, through a different mechanism.
} 
(Weller, 2010). Apart from the formal title, it has no other content than effective participation in decision-making in the area of culture. It follows that the international standards on participation can be used to assess the quality of cultural autonomy arrangements and to conceptualize cultural autonomy as a right, as a requirement of international human rights law. The qualitative criteria developed here are thus applicable to both, since, on a conceptual level, cultural autonomy is a sub-category of the right to effective participation.

\section{International Human Rights Standards on Cultural Autonomy}

The Council of Europe's Framework Convention for the Protection of National Minorities is the only binding multilateral human rights treaty focusing on minority rights (Vacca, 2010). It recognizes a wide range of rights, but the right to autonomy is not among them-at least not formally. The Convention does require states to create the conditions necessary for minorities to maintain and develop their culture (Article 5) and for effective participation of minorities in cultural life and public affairs, in particular, those affecting them. Reading these provisions in conjunction, minorities have a right to effectively participate in decision-making on issues relating to their culture. ${ }^{3}$

The right to effective participation had been articulated on the international level before the adoption of the Framework Convention, notably in paragraph 35 of the Organization for Security and Co-operation in Europe (OSCE) Copenhagen Document of the 1990 Conference on the Human Dimension (Weller, 2010), and the United Nations Declaration on the Rights of Persons Belonging to National or Ethnic, Religious and Linguistic Minorities. ${ }^{4}$ These were, however, political documents. The right was recognized as a legally binding norm only with the adoption of the Framework Convention (Weller, 2004).

According to the Convention's Explanatory Report, the aim of Article 15 is real equality between members of minority communities and the majority (Weller, 2004). To achieve this goal, states can use a number of mechanisms: consultation with minorities; their involvement in preparing and implementing development plans; undertaking studies to assess the impact of decisions; effective participation of minorities in the decision-making process; and decentralised forms of government (Weller, 2004).

The Advisory Committee on the Framework Convention, the body responsible for monitoring and implementing the Convention, clarified the content of effective participation in its country reports and its second thematic commentary. According to the Committee, the state's role under Article 5 is to guarantee an effective right to identity. ${ }^{5}$ To achieve this purpose, states have to ensure an effective participation of minorities in cultural life, which has the following components: If persons belonging to minority communities are affected by the design or implementation of cultural policies, including the allocation of support for minority cultures, national minorities must be adequately consulted by the authorities and involved in the decision-making process in order for their needs to be met effectively. ${ }^{6}$ If specific institutions exist for channelling such support, minorities should be adequately represented in them and should be able to take part in the corresponding decision-making. ${ }^{7}$

\footnotetext{
${ }^{3}$ Explanatory Report to the FCNM, H(95) 10, February 1995, para. 80.

${ }^{4}$ General Assembly Resolution 47/135, 18 December 1992, Art. 2, para. 3.

5 Commentary on the effective participation of persons belonging to national minorities, Adopted on 27 February 2008 , ACFC/31DOC(2008)001, para. 14.

6 Ibid., para. 66.

7 Ibid.
} 
Mere representation in elected bodies may be insufficient to meet the Convention's demands. Consultative bodies must be inclusive and representative, with transparent appointment procedures. ${ }^{8}$ National minorities must receive capacity-building and resources to enable them to contribute effectively to the decision-making process. ${ }^{9}$

The key term of Article 15 is "effectiveness" (Verstichel, 2010, p. 452). The Advisory Committee does not define it in abstract terms. It nevertheless specifies that effectiveness depends both on the means of involvement and on the impact on the situation of the persons concerned and society as a whole. ${ }^{10}$ This impact has qualitative and quantitative dimensions. ${ }^{11}$ Minorities must have a "substantial influence" on decisions taken. $^{12}$

With regard to decision-making in matters of cultural life, the Committee specifically endorses delegation of competences to cultural autonomies. ${ }^{13}$ According to the Committee, cultural autonomies can result in increased participation of minorities in cultural life, ${ }^{14}$ and can contribute to the preservation of minority cultures. $^{15}$

The above criteria thus represent the core requirements relating to participation in decision-making in cultural affairs: inclusiveness, representativeness, transparency, adequacy (of consultation), and effective participation in decision-making, which requires substantial influence over decisions.

Several commentators criticised the Advisory Committee's approach as offering little legal substance in operationalizing the right to effective participation in practice. Indeed, the Committee's general criteria are rather vague, but they can be specified when reviewing the specific mechanisms of state parties to the Framework Convention (Weller, 2004). How these rather abstract terms were interpreted by the Advisory Committee in the case of Slovakia will be analysed below, after the Slovak system of support for minority cultures is introduced.

\section{The Slovak System of Support for Minority Cultures}

The Slovak Republic is a diverse country, where approximately 12.3 per cent of the population declared an ethnicity different from Slovak in the last census, ${ }^{16}$ and 13.9 per cent has a mother tongue which is not Slovak. ${ }^{17}$ Consequently, many cultural activities take place in minority languages. These include, for example, newspapers, TV broadcasting, music and arts festivals, and dance ensembles. The state supports cultural activities through a funding scheme administered by the Ministry of Culture, which has existed in its current form since $2015 .^{18}$

\footnotetext{
${ }^{8}$ Ibid., para. 7.

9 Ibid., para. 21

10 Ibid., para. 18.

11 Ibid.

12 Ibid., para. 19.

13 Ibid., para. 67.

14 Ibid.

15 Ibid., para. 135.

16 Statistics on the population's ethnic composition are available from: https://slovak.statistics.sk/wps/wcm/connect/1f62189f-cc70-454d-9eab-17bdf5e1dc4a/Tab_10_Obyvatelstvo_SR_podla_narodnos ti_scitanie_2011_2001_1991.pdf?MOD=AJPERES\&CVID=knLHmhe\&CVID=knLHmhe.

17 Statistics on the population's mother tongue are available from: https://slovak.statistics.sk/wps/wcm/connect/65804666-cc85-4ac6-bacd-acb0bba52ed8/Tab_11_Obyvatelstvo_SR_podla_materin skeho_jazyka_SODB_2011_2001.pdf?MOD=AJPERES\&CVID=knLHmAz\&CVID=knLHmAz.

${ }^{18}$ Law No. 284/2014 Col. 1. on the Fund for the support to arts (Zákon o Fonde na podporu umenia), 12 September 2014.
} 
Despite the ubiquity of national minority cultural activities and organizations, the state does not have a constitutional obligation to provide support for minority cultures. Article 34(1) of the Constitution only permits citizens belonging to minority communities to develop their culture and establish cultural institutions. ${ }^{19}$ This can be considered a codification of personal autonomy: Members of minority communities can freely establish their organizations and pursue any goal, including the promotion of their culture, but they are not entitled to public support to achieve these goals (Suksi, 2008). In Article 34(2), the Constitution also guarantees the right of members of national minorities to participate in matters affecting them, without specifying culture as a specific area of concern for minorities, nor requiring the participation to be effective (Petöcz, 2010). ${ }^{20}$

Notwithstanding the lack of a constitutional obligation, the political practice of the country has been to set aside a certain amount of funding specifically for minority cultural activities, dividing this sum among the respective minority communities and supporting activities which representatives of these communities have chosen. $^{21}$ This system was established as a political compromise at the time when the Party of the Hungarian Coalition, representing the largest minority group, the Hungarian community, was part of the government between 1998 and 2006 (Petőcz, 2010). It has been maintained since then, but without any legal guarantee. The legal framework on state support has only regulated the general rules for providing state support. Each year, it was a matter for a political decision how much the state allocated for minority cultural activities, how it was to be divided among the different communities, and what would be the mechanism for distributing it (Fiala-Butora, 2016). Naturally, the outcomes depended on the bargaining position of minority communities and particularly on whether representatives of the Hungarian community were part of the government coalition or the parliamentary opposition (Petöcz, 2010). ${ }^{22}$ The system was a source of frequent political tensions, not only between the Slovak majority and the minority communities, but also among different minority communities ${ }^{23}$ and within specific minority communities as well. ${ }^{24}$

This unregulated form of cultural proto-autonomy was in effect until 2017, when a new law on financing minority cultures was adopted by parliament, which formalized some of the existing practices and reformed others. ${ }^{25}$ This law will be analysed in detail in Part "Evaluating the Slovak Law on Autonomy". Before that, the following analysis looks at how the Slovak system fared when scrutinized from the perspective of international requirements. More specifically, how the Advisory Committee evaluated its weaknesses under the Framework Convention.

\footnotetext{
19 Law No. 460/1992 Col. 1. on the Constitution of the Slovak Republic, 1 September 1992.

20 Petöcz (2010, p. 739) considered this provision to codify the principle of effective participation, but the text does not include the word "effective", only "the right to participate".

${ }^{21}$ (First) Report submitted by the Slovak Republic pursuant to Article 25, paragraph 1 of the Framework Convention for the Protection of National Minorities, received 4 May 1999, ACFC/SR(1999)008, p. 12.

${ }^{22}$ See Petöcz (2010, p. 749), arguing that it was difficult even for Hungarians when they were part of the influence issues relating to their identity; it was even more difficult when they were not part of the government coalition, and more difficult for smaller minorities which were not represented in Parliament.

23 "Dotácie rozhádali menšiny, Mad’ari nahnevali Poliakov a Čechov" (Minorities argue over grants, Hungarians upset Poles and Czechs), Sme, 30 January 2013.

24 “A SZMK Koordinációs Bizottságának állásfoglalása a kormányhivatal 2011-es évi nemzeti kisebbségek kultúrájának támogatásával kapcsolatban és Juhász László válasza” (Position of the Coordination Committee of the RHS on the Government's Office support to minority cultures in 2011 and the response of László Juhász), Press release of the Roundtable of Hungarians in Slovakia, 16 July 2011

${ }^{25}$ Law No. 138/2017 Col. 1. on the Fund to support the culture of national minorities, 10 May 2017.
} 


\section{Slovakia's Support for Minority Cultures in the Light of International Requirements}

The Advisory Committee has regularly considered the compatibility of the Slovak system of financing minority cultures with Article 5 of the Framework Convention since the first reporting period. In its first opinion on Slovakia, issued in 2000, it did not comment on the allocation of funds and their mechanism, ${ }^{26}$ although in its report the Slovak government provided extensive information about how the funding scheme operated. ${ }^{27}$ At that time, the Minister of Culture determined the allocation of funds on the recommendations of an expert committee composed of members of six out of 12 minority communities and representatives of state bodies and scientific institutes. ${ }^{28}$ The state reported that in 1998 it allocated 44.594 million Slovak crowns, ${ }^{29}$ approximately 1.14 million euros, for the support of minority cultures. ${ }^{30}$ In its opinion, the Advisory Committee only commended the state for increasing its efforts to promote minority cultures, and recommended close consultation and cooperation with the Roma community in designing and implementing initiatives aimed at promoting Roma culture. ${ }^{31}$

In its second opinion on the Slovak Republic, the Advisory Committee commended the state for raising the sum allocated for minority culture ${ }^{32}$ to 80 million Slovak crowns in 2003 (approximately 1.92 million euros). ${ }^{33}$ However, it was concerned about the low support allocated to the Roma minority. ${ }^{34}$ The Roma community's share was calculated according to the census results, which did not reflect the actual number of Roma. The Advisory Committee recommended taking other sources into account when estimating the size of the Roma community, such as surveys and scientific studies. ${ }^{35}$ The Advisory Committee also noted with satisfaction the proposed draft law on the financing of minority cultures, which was to replace the funding system based on ad hoc governmental resolutions. ${ }^{36}$ The Committee noted that several minority communities welcomed the new law, and recommended speeding up the process of its adoption and ensuring proper participation of their representatives in this process. ${ }^{37}$

In the third reporting period, by 2009 , the government had increased the budget allocated to minority culture to 100 million Slovak crowns, or 3.34 million euros. ${ }^{38}$ Apart from this increase, the Advisory Committee had little to be satisfied with. It noted the lack of transparency in the funding allocation mechanisms. ${ }^{39}$ In particular, it received complaints about how certain representatives of minority communities were appointed to the grant commissions. ${ }^{40}$ It also noted with regret that the law on financing of minority

26 (First) Opinion on Slovakia, adopted on 22 September 2000, Advisory Committee on Framework Convention for the Protection of National Minorities, ACFC/INF/OP/I(2001)001, paras. 22-24.

27 (First) Report submitted by the Slovak Republic, supra note 6, p. 12.

28 Ibid.

29 Ibid., p. 15.

30 Historical exchange rates taken https://www.nbs.sk/sk/statisticke-udaje/kurzovy-listok/kurzovy-listok/mesacne-kumulativne-a-rocne-prehlady-nbs.

31 (First) Opinion on Slovakia, supra note 26, §22-24.

32 Second Opinion on the Slovak Republic, adopted on 26 May 2005, ACFC/OP/II(2005)004, para. 61.

33 Second report submitted by the Slovak Republic pursuant to Article 25, paragraph 1 of the Framework Convention for the Protection of National Minorities, received 3 January 2005, ACFC/SR/II(2005)001, p. 21.

34 Second Opinion on the Slovak Republic, supra note 32, para. 63.

35 Ibid., $\$ 65$.

36 Ibid., $\$ 60$.

37 Ibid., $\$ 64$.

38 Third report submitted by the Slovak Republic pursuant to Article 25, paragraph 1 of the Framework Convention for the Protection of National Minorities, received 22 July 2009, ACFC/SR/III(2009)008, p. 20.

39 Third opinion on the Slovak Republic, adopted on 28 May 2010, ACFC/OP/III(2010)004, para. 65.

40 Ibid. 
cultures had not been adopted. ${ }^{41}$ It criticized the government for amending the rules on language use in cultural events. According to the new provisions of the State Language Act, all publications in minority languages for cultural purposes, such as programmes and catalogues, had to be fully translated into Slovak. ${ }^{42}$ The Committee recommended that this provision be implemented in a way which would not place an unreasonable burden on minority organizations, for example, by requiring only the translation of extracts, outlines or summaries. ${ }^{43}$

The fourth reporting period is particularly informative for the purposes of this analysis, because the Advisory Committee's opinion can be compared not only with the state report, but also with a shadow report prepared by an umbrella association of Hungarian civil society organizations in Slovakia, which was available to the Committee. ${ }^{44}$

The support allocated for minority culture decreased in the reported period since 2012, from 4.5 million euros in 2012 to 4.25 million euros in 2013 and 3.83 million in $2014 .^{45}$ The Committee noted that several minority communities, especially smaller ones, consider the funding insufficient to maintain their culture. ${ }^{46}$

The Committee did not criticize the funding allocation among different minorities. Members of the Hungarian community account for approximately 70 per cent of the minority population of Slovakia according to the census. Yet the shadow report shows that the sum allocated to the Hungarian community fell from 55 per cent in 2012 and 61 per cent in 2013 to 51.7 per cent in $2014 .{ }^{47}$ In 2014, even the sums allocated to small minorities were out of balance. The per capita sum allocated to the Jewish minority was 88 euros, for Croats 48.31 euros and for Serbs 39.7 euros. $^{48}$ At the same time, the Czechs received 6.8 euros per capita, Moravians 8.5 euros and Ukrainians 14.6 euros. In the case of more numerous minorities, the allocation was 4.33 euros for Hungarians, 6 euros for Roma and 7.9 euros for Ruthenians. ${ }^{49}$

While it is understandable that less numerous minorities receive a higher per capita allocation than larger communities, this principle cannot explain the allocated sums. For example, Moravians were three times as numerous as Croats, but received only half the sum allocated to the latter community. Poles were less numerous than Moravians, yet they received twice the amount of funding.

The Committee did not find a problem in this allocation system. It only noted that numerically larger minorities were critical of the per capita amounts, but this can be justified in the Committee's view given the smaller minorities' need for specific assistance. ${ }^{50}$ The Committee did not comment on the limits of this principle, nor on the imbalance in the funding allocations to smaller minorities, implicitly accepting these.

The Committee also noted that the allocation process was changed in the sub-committee responsible for allocating funds among different minority communities. Prior to 2013, numerically larger minorities had more

41 Ibid., $\$ 74$

${ }^{42}$ Law No. 318/2009 Col. 1. amending law no. 270/1995 Col. 1. on the State language of the Slovak Republic, 30 June 2009, $\S 5(5)$.

43 Third opinion on the Slovak Republic, supra note 39, para. 68.

${ }^{44}$ Written Comments by the Roundtable of Hungarians in Slovakia (RHS) on the Fourth Report submitted by Slovakia on the implementation of the Framework Convention on the Protection of National Minorities, 30 July 2014.

${ }^{45}$ Fourth report submitted by the Slovak Republic pursuant to Article 25, paragraph 1 of the Framework Convention for the Protection of National Minorities, received 28 January 2014, ACFC/SR/IV(2014)001, pp. 46-47; Written Comments by the Roundtable of Hungarians in Slovakia (RHS), supra note 44, paras. 36 and 37.

${ }^{46}$ Fourth opinion on the Slovak Republic, adopted on 3 December 2014, ACFC/OP/IV(2014)004, para. 28.

47 Written Comments by the Roundtable of Hungarians in Slovakia (RHS), supra note 44, para. 37.

48 Ibid.

49 Ibid.

${ }^{50}$ Fourth opinion on the Slovak Republic, supra note 46, para. 36. 
votes in the committee: Hungarians had five votes; the Roma had four, while the Ukrainians, Czech, and Ruthenians had two. After November 2013, each community had one vote regardless of its size. The Advisory Committee noted that the new system raised concerns among the larger minorities and recommended that constructive dialogue be conducted with all communities. ${ }^{51}$ It recommended the same with regard to the language requirements relating to publications in connection with cultural events, which continued to create tensions, despite the change in legislation. ${ }^{52}$

The Committee did not comment on the continuing absence of the law on financing minority cultures. It only suggested promotion of the effective participation of national minority representatives in relevant decision-making in general. ${ }^{53}$

Overall, the Advisory Committee's position on the financing of minority cultures in Slovakia can be evaluated as contradictory. On the level of principles, the Committee stresses effective participation and transparent decision-making procedures. ${ }^{54}$ However, in practice, it applied these principles in a very questionable way. When compared with the situation on the ground as established from the shadow report, the Committee's approach can be characterized as legitimizing unjustified limitations on minority rights. The Slovak funding disbursement mechanism was characterised with dubious and unexplained allocations of funds among minority communities, in a non-transparent mechanism where representatives of 70 per cent of the members of the affected minority communities held 7.7 per cent of the votes. ${ }^{55}$ The Committee characterised this state of affairs as a subjective complaint of an aggrieved community, rather than an objective issue of compliance under the Framework Convention. This sets the level of compliance very low. In the Committee's view, the remedy simply requires "constructive dialogue", rather than, for example, changing the rules. ${ }^{56}$ It is hard to understand how an unsatisfactory system becomes acceptable if the affected communities are consulted, but the problematic practices remain in force.

The Committee could have proposed solutions which would implement the requirements of transparency and inclusion, but did not do so. In the last reporting period, it even refrained from recommending the adoption of a law on the financing of minority cultures, which had been a recurrent theme in earlier reporting cycles. The Committee's views have thus become less relevant, if not to say irrelevant, with regard to the most debated questions of minority culture in Slovakia. While the Framework Convention and the principles deriving from it remain a valuable starting point for establishing a normative framework for operationalizing cultural autonomy, the Committee's specific comments about Slovakia are of little help in this regard.

The Committee's position on Slovakia is in line with its general approach to Article 15. Several commentators have criticized it as vague and offering little substance (Weller, 2004). The Committee largely adheres to commenting on existing mechanisms (Verstichel, 2010) and identifying best practices in members states (Weller, 2004). While this may be a useful approach in the case of states looking for good solutions to implement, it cannot be considered an effective enforcement of human rights norms in states that are falling below the Committee's general standards. For that, the Committee would need to identify specific criteria by which the quality of specific mechanisms is assessed, and enforce these criteria in states that are not willing to

\footnotetext{
51 Ibid., para. 32.

52 Ibid.

53 Ibid., para. 33.

${ }^{54}$ Commentary on the effective participation of persons belonging to national minorities, supra note 5, para. 66 .

55 Fourth opinion on the Slovak Republic, supra note 46, para. 32.

56 Ibid., para. 29.
} 
adopt them. The following sections will analyse the new Slovak Law on support for minority cultures, in order to identify such criteria that can be adopted by the Committee.

\section{The 2017 Law on the Financing of Minority Cultures}

The Law on the Fund to Support the Culture of National Minorities was adopted by the Slovak Parliament on 10 May $2017 .^{57}$ Its adoption was not justified with the need to comply with the country's international or constitutional obligations. The Law and its explanatory report do not even refer to the Framework Convention-a visible and telling sign. ${ }^{58}$ The law is presented as a result of the government's coalition agreement, drawing upon the positive experiences with similar funds established for supporting audio-visual culture in 2009 and a general fund for supporting culture in 2014. ${ }^{59}$

The law was in fact the result of a long political struggle on the part of the Hungarian community. Several proposals had been developed since 2012, but they were either withdrawn after the fall of the government in $2012^{60}$ or rejected by the parliamentary majority in $2015 .^{61}$ After the elections of 2016, when the Most-Híd Party, partly representing the Hungarian community, formed part of the ruling coalition, the adoption of the law was one of their conditions, which became an element of the coalition agreement and the government's programme. ${ }^{62}$

The new law on the Fund to support minority culture is in many ways simply formalizing the best practices of previous experiences with participation of minority communities in decision-making affecting them. It sets up a Fund for the Support of the Culture of National Minorities as a separate legal entity, with its own budget and powers to distribute it among different communities and applicants. ${ }^{63}$ The Fund also has some internal rule-making powers: While it cannot change the legislative environment in which it is operating, it can adopt its own procedures and substantive rules for allocating funds. ${ }^{64}$ This is not a mere technicality: "Rules" can be a very broad term, and by setting rules on preferred and supported activities, the Fund can exert a lot of influence on how minority cultures will develop, which areas will strive and which will be discontinued.

The Fund is represented by its director, appointed by the Minister of Culture. ${ }^{65}$ The main decision-making bodies are the expert councils, three for each minority community and one for inter-cultural activities. ${ }^{66}$ The three councils for minority communities are responsible for evaluating funding applications in the three substantive areas: (a) cultural and educational activities; (b) literature and publishing; and (c) theatre, music, dance, artistic, and audio-visual activities. ${ }^{67}$ From their five members, three are elected by representatives of minority cultural organizations and two are appointed by the Fund's director. ${ }^{68}$

\footnotetext{
57 Law No. 138/2017 Col. 1. on the Fund to support the culture of national minorities, 10 May 2017.

58 Explanatory report to Law no. 138/2017 Col. 1. on the Fund to support the culture of national minorities, General part, 10 May 2017 , p. 1.

59 Ibid., p. 2

${ }^{60}$ Legislative proposal from 2011 on the protection and support of preservation and development of the culture of national minorities, 16 September 2011.

${ }^{61}$ Legislative proposal from 2015 on the Fund to support the culture of national minorities, 28 August 2015.

62 Declaration of the Government's Program for years 2016-2020, 26 April 2016, p. 45.

${ }^{63}$ Law on the Fund to support the culture of national minorities, supra note $25, \S 1$.

64 Ibid., §7(3) and especially $\$ 13(1)$.

65 Ibid., \$4(5).

${ }^{66}$ Ibid., §7(4). Communities that do not find enough experts to establish three councils can decide to establish one council instead according to $\S 7(10)$ of the Law.

${ }^{67}$ Ibid., \$7(9)

68 Ibid., §7(6).
} 
The Act sets the Fund's budget at "at least" 8 million euros, to be paid from the national budget. ${ }^{69}$ It also sets the share allocated to each minority community from this sum. ${ }^{70}$ The Act thus aims to overcome the toxic yearly political disputes over allocations of support for the culture of specific communities. Whether it has chosen an effective method will be evaluated below in Part "Evaluating the Slovak Law on Autonomy". Before that, a theoretical discussion will establish the criteria for evaluating the effectiveness of the mechanism established by the law. Applying these criteria to the new law and the debates concerning its adoption, the closing part will evaluate the law from a perspective of an ideal cultural autonomy framework, and draw conclusions for operationalizing the relevant provisions of the Framework Convention on the effective participation of minorities in matters affecting their culture.

\section{The Need for and the Purpose of Cultural Autonomy}

Do minority communities even need a separate mechanism to finance their "own" cultural activities? Can culture be divided into "majority" and "minority" culture, and what are the criteria for such a division? Should not the state's goal be to ensure that all citizens, regardless of their ethnicity, can consume and produce any cultural goods of their choice? And in that case, is it not more effective to finance all cultural activities through one funding mechanism, making sure that no one is disadvantaged in the process due to their perceived ethnicity? These were some of the questions raised during the public debate about the Act on the Fund for the Support of Minority Cultures. ${ }^{71}$ To establish the criteria for effective cultural autonomy mechanisms, one needs to first justify the existence of separate mechanisms; both goals are achieved by identifying the problem autonomy seeks to solve.

While different criteria could be raised in the abstract regarding what constitutes a separate culture, in the case of Slovakia the answer is rather simple: Each minority community has its own language, therefore their culture mostly refers to cultural expressions in their languages. This is a rule of thumb rather than an entirely satisfactory approach: Some in the arts world tend to use a language other than that of their community, such as Roma or Jewish poets writing in Slovak or Hungarian. Furthermore, some forms of art are not language-based, such as dance, music, sculpture, painting, and others. In those cases, the activity can be categorized on the basis of the performers' ethnicity. While several objections could be raised on the theoretical level in relation to classifying certain cultural practices as "belonging" to one community or the other, in practice, this issue has resonated surprisingly little in Slovakia. Cultural organizations' self-identification about their belonging to a certain community is the rule, and it is rarely if ever challenged in practice. ${ }^{72}$ For the purposes of our analysis, we can accept that there are separate cultures in Slovakia, with their own cultural organizations.

The existence of separate cultures does not in and of itself justify separate funding mechanisms. If only one, mainstream funding mechanism existed, would it necessarily lead to unfair treatment of smaller communities? Perhaps a system without discrimination can be imagined, but not one without contradictory interests. In the case of Slovakia, communities speak their own languages. While members of the Slovak majority are certainly not prohibited from participating in a Hungarian theatre show or reading a Romani newspaper, in the absence of understanding these languages they are very unlikely to do so. They might still

\footnotetext{
${ }^{69}$ Ibid., § 21(1).

${ }^{70}$ Ibid., §22(1)

71 "Menšiny na Slovensku si zaslúžia viac" (Minorities deserve better), Zora Jaurová, DenníkN, 17 March 2014.

72 Law on the Fund to support the culture of national minorities, supra note 25, §7(8)b.
} 
prefer for these cultural goods to exist for the sake of speakers of these languages, but they do not have personal preferences among them. Due to language barriers, they are not themselves consumers of these cultural goods, therefore they are not efficient decision-makers when it comes to deciding what areas of minority culture should be supported at the expense of others. Only members of the specific communities, with both expertise and a stake in the question, are in a position to decide what deserves support from cultural expressions relevant to their specific language and traditions.

It follows from the above that regardless of the form of the mechanism, it is crucial to gather specific input from the affected communities. Whether this is done in committees or advisory bodies of one general funding scheme or specific schemes are established for specific communities, the underlying principle is the same: Affected persons are the best decision-makers when it comes to allocating funds.

A mainstream funding mechanism without any specific provisions for minority involvement cannot satisfy this principle. By definition, it will be governed mainly by members of the largest, the majority community. Regardless of their benevolence, they will not be in a position to effectively decide questions of cultural policy for other communities.

Similarly to the majority culture, minority cultures also need financial support, the setting of priorities and development policies. For the majority culture, these decisions are made through the ordinary political process: Citizens elect their representatives in a general parliamentary election, who then constitute and control the executive responsible for creating and implementing the state's cultural policy. The role of cultural autonomy is to provide a similar mechanism for minority communities, to make the same decisions, to devise, and implement cultural policy for minority cultures. Its goal is achieving substantive equality for minorities in decision-making over their own matters (Verstichel, 2010). Since members of minority communities do not constitute separate political communities, they need other mechanisms to select and control their representatives responsible for cultural policy. In effect, cultural autonomy in this area is the operationalizing of the principle of effective participation of minority communities in matters affecting them, specifically in matters affecting their cultural activities.

Effective participation in decision-making cannot simply mean that some persons will make decisions in the name of a certain community (Palermo, 2010). The decisions must reflect the wishes of the members of the community. The connection between community and decision-makers is never perfect. It runs into the well-known principal-agent problem and the collective action problem. The ethnic majority solves these problems by aggregating individual preferences through the political process. Cultural autonomy is a solution of these problems for minority communities, whose interests are not adequately reflected in the ordinary political process.

The principal-agent problem rests on the disconnection between the represented and the representatives, and the latter's' accountability to the former (Weller, 2010). Participation in decision-making is effective only if members of the community have control over who makes decisions in their name and what decisions are made (Verstichel, 2010). Ideally, this would require elections of decision-makers and binding their decision-making authority by clear rules agreed upon by the community.

The collective action problem refers to the inability of individual members of the community to harmonize their actions and bind other members of the community to their decisions. For example, individual members of the community have no power to adopt those rules on the priorities of cultural policy which should bind the decision-makers. The obstacles are practical and also legal. It takes time, effort and resources to coordinate the 
creation of a policy document which takes into account the views of all relevant stakeholders. It is in the interest of all members of the community for such a process to take place, and in all likelihood most would agree to dedicate a certain sum or effort for that purpose. However, no one is in the position to bind other members of the community to commit their share. In this situation, everybody is better off not taking any action on their own. Even if some person or persons would take action, they would not have the legal power to bind others to the results they reached, undermining the fruits of their enterprise (Petöcz, 2010).

This is exactly the result of minorities' efforts in Slovakia-Since the establishment of democracy, no minority community has been able to create a policy document reflecting its members views regarding the development of their culture. Theoretically, any cultural organization could have produced such a document and could have organized the process to involve all stakeholders. Perhaps some of them could even muster the necessary resources, especially organizations from the larger communities. Nevertheless, it did not happen. Instead of blaming minority organizations, it is important to recognize the underlying structural problem: For collective action to be effective or even possible, it must be institutionalized in some way, with the necessary powers and resources. In the case of the majority community, the state implements cultural policy through its political institutions: parliament, the government, and affiliated bureaucracy. The purpose of cultural autonomy is, inter alia, to fulfil this collective function for minority communities. Without that, it is much more difficult for minorities to take collective action than for members of the majority.

The effectiveness of cultural autonomy mechanisms is always relative. The yardstick is how well they overcome the collective action problem and agency problem embedded in representative decision-making. This is not different from majority decision-making: The mainstream political process also overcomes these obstacles only to some extent. Nevertheless, by assessing how a specific solution responds to the obstacles, it is possible to differentiate effective participatory mechanisms from those that are autonomous in name only.

\section{The Qualitative Indicators of Autonomy}

From the above theoretical framework we can derive the criteria for establishing whether a cultural autonomy arrangement promotes the effective participation of minorities in decision-making related to the development of their own culture.

The system needs a clear mechanism guaranteeing a fair share of minority communities in the public funds dedicated to culture. The respective communities should receive a yearly amount proportionate to their share of the population. The Advisory Committee commends the positive discrimination of less numerous minorities in this regard, which seems to be a reasonable rule. ${ }^{73}$ It is important, however, that the respective shares or the mechanism by which they are determined are settled and formalized, so that the distribution of funds ceases to be an annual political decision-One in which the national majority has the decisive word. Effective control over the funds required for promoting a community's own culture requires that the decision concerning how much each community receives is not taken unilaterally by the majority.

The next criterion relates to how decisions are made about allocating funds to specific goals identified by each community. It is important that the decision-makers represent the respective community. This can be achieved through some form of direct or indirect election. The second aspect relates to the nature of the decisions: They must be final, not simply recommendations or advisory opinions that can be overruled by other

\footnotetext{
${ }^{73}$ Fourth opinion on the Slovak Republic, supra note 46, para. 28.
} 
decision-makers. The communities' representatives must exercise effective decision-making powers. The state might have a legitimate reason for interfering with decisions in this area, such as upholding the general laws on corruption and conflicts of interest. Nevertheless, the basis for interference should not be a wide, general authorization, but a narrow one, based on clear criteria. The former could lead to frequent and unjustifiable overturning of the community's decisions, which undermines effective decision-making and leads to injustice.

Elected decision-makers must not act arbitrarily. Their decisions about the allocation of funds must follow some public evaluation criteria, reflecting the goals of the specific community in the area of promoting its culture. This not only ensures accountability, but allows the community to formulate priorities, to decide what share of funds should be allocated to different activities, and how activities in specific areas should be compared to each other, what should be valued more and what less. Such a document on cultural policy can have different degrees of precision, depending on the volume of funded activities, which relates to the community's size, its needs and experience with self-government. But some form of publicly accessible criteria regarding cultural priorities is necessary for giving guidance to decision-makers and eventually for reviewing their decisions.

The fund allocation system must have the necessary legal guarantees against outside interference. ${ }^{74}$ Ideally, this means a constitutional guarantee, with detailed legislative rules implementing the constitutional provisions. This provides the system with the necessary stability and protects minority communities from the overruling of their decisions by state actors. The legislative framework should be mindful of the specific needs of minority communities. The general rules on cultural policy applicable to mainstream or majority institutions might not always be appropriate for minority institutions.

Transparency is very important not only for countering corruption, but also to ensure that the community's stated cultural policy goals are being followed. The criteria for decisions, individual decisions themselves, the evaluation of projects and overall data about the system's functioning should be easily accessible for the public.

Related to transparency, any kind of decision must be made with the involvement of the respective community at large. This seems to be such an elusive condition that it is questionable whether it can become a legal requirement. It is hard to define who constitutes the relevant community, when it is sufficiently involved, or what happens if its members are not interested in taking part in the process, despite having the opportunity. Nevertheless, it is hard to imagine the autonomy of minority communities without some involvement of the wider community in the decision-making process.

\section{Evaluating the Slovak Law on Autonomy}

The above criteria measuring the effectiveness of participation are quite general. They can be specified by applying them to a specific context: the new Slovak system of financing minority cultures. The goal of this exercise is twofold: It will highlight some of the difficulties and solutions to operationalizing the criteria in a specific context, and will also assess how the Slovak mechanism fares under the criteria.

\section{A Guaranteed Fair Share for Minority Cultures}

While seemingly an easy arithmetic exercise, a fair share for minority cultures is in fact a very elusive concept. What culture and minority culture are and how funds spent on them should be counted all need defining, as does how the size of communities needs to be taken into account.

\footnotetext{
${ }^{74}$ Commentary on the effective participation of persons belonging to national minorities, supra note 5, para. 107.
} 
Culture can be defined very widely, but for the purposes of cultural autonomy the analysis can be restricted to cultural activities financed by the state. Presumably, if one identified the whole sum spent on all such activities from public funds, a share proportionate to each minority community's size could be considered fair. However, even "cultural activities financed by the state" might not be that easy to determine. Should, for example, national television or public museums be included? Should these count only as part of the majority culture? If they broadcast in minority languages, or have signs in minority languages, should they also be considered part of minority culture(s)?

An earlier Slovak legislative proposal from 2011 considered the budget of the Slovak Ministry of Culture as the reference point from which the contribution to minority communities should be determined, excluding from the baseline separately funded public broadcasting, museums, theatres and other major cultural establishments. ${ }^{75}$ During discussion of the 2017 law, minority communities proposed to tie the financing of minority cultures to the budget of the Fund for Arts and Culture, which has a similar purpose and finances similar activities as the Fund for the Support of Culture of National Minorities. ${ }^{76}$

The mechanism finally chosen in 2017, however, is much simpler. The law declares that at least 8 million euros must be dedicated to minority culture from the state budget every year. ${ }^{77}$ This sum is almost double the sums allocated in previous years; therefore, it can appease the minority communities in the short term. Nevertheless, it cannot be considered a satisfactory systemic solution. It leaves raising the yearly allocation in the hands of the government. It will be essentially the national majority which decides whether to increase allocations to minority culture to keep up with inflation, or with higher sums eventually allocated to the majority culture. It will also be possible to decrease the sum in the future if it does not fall below the guaranteed 8 million euros. Minority communities thus do not have a guarantee of financial stability for their cultures. Tying the sum in some way to the amount allocated to the majority culture, so that they increase or decrease in the same way, would have been a more difficult legislative exercise, but certainly a solution ensuring more effective minority self-government in financing.

The second difficulty lies in how to divide the allocated sum among the specific minority communities. Less numerous communities need to receive some positive discrimination so that they can cover the fixed costs necessary to run cultural establishments. But what should be the rate of this positive discrimination? Should all minority communities be the beneficiaries of such discrimination compared to the majority culture, or should more numerous minorities cover the costs of positive discrimination of smaller minorities? How should even the size of the communities be established, by declarations of ethnicity or mother tongue, or a combination of both? Should persons who did not declare any ethnicity be discounted, or counted as part of the majority?

The 2017 law chose to define the share of each minority community in specific percentages. ${ }^{78}$ The explanatory report explains that these percentages are based on the 2011 census declarations on ethnicity and mother tongue, and are modified to take into account the interests of smaller communities. ${ }^{79}$ The outcome was

\footnotetext{
75 Legislative proposal from 2011 on the protection and support of preservation and development of the culture of national minorities, supra note $39, \S 14(1)$.

${ }_{76}$ Comments of the Hungarian community on the proposed Law on the Fund to support the culture of national minorities, 10 August 2016, p. 12.

${ }^{77}$ Law on the Fund to support the culture of national minorities, supra note 25, §21(1).

78 Ibid., 22(1).

79 Explanatory report to Law No. 138/2017 Col. 1. on the Fund to support the culture of national minorities, Specific part, 10 May 2017, p. 7.
} 
eventually the result of a political decision, with no detailed calculations being put forward. As negotiations on the draft bill were ongoing, the share of smaller communities was rising at the expense of the largest, the Hungarian community. Hungarians, who constitute approximately 70 per cent of all minorities according to ethnicity, were allocated 59.6 per cent according to earlier drafts, ${ }^{80}$ and 53 per cent according to the final law. ${ }^{81}$

A specific problem relates to the Roma community, whose members are notoriously underrepresented in the censuses. Their share in an earlier draft law was set at 14.4 per cent, on the basis of ethnicity figures from the last census. ${ }^{82}$ This was raised to 22.4 per cent in the final law, ${ }^{83}$ taking into account figures from the Atlas of Roma communities. ${ }^{84}$ This approach raises two major problems.

First, the Roma atlas was created for a different purpose than the allocation of cultural funds. ${ }^{85}$ It maps the number of Roma based on social exclusion (poverty, residence in a segregated Roma community) and identification as Roma by others based on external characteristics (who "looks" Roma). ${ }^{86}$ It basically defines Roma as a racial/social category. In the 1990s, the Roma in Slovakia were indeed officially considered an "ethnic group", a different category than other national minorities, but this differentiation was eliminated because it had no legal relevance (Petőcz, 2010). It is likely that the number of persons identifying with Roma culture is significantly lower. While other commentators have suggested that the different uses of the term Roma cause confusion and have suggested a unified approach, this does not seem to be warranted in the case of cultural autonomy (Pap, 2015). The purpose of this institution is very different than, for example, that of anti-discrimination laws that rely on external markers of ethnicity, or of social-economic measures that take social exclusion and social status into account. For the purposes of cultural autonomy, the relevant number is that of Roma identifying with Roma culture, which is not what the Slovak law has chosen.

Second, while it is true that censuses underreport the number of Roma, the same is also true for other and perhaps all minority communities. For example, the number of Hungarians based on cultural characteristics is estimated at 610,000, while those declaring Hungarian ethnicity numbered 456,000 in the last census (Ravasz, 2012). If the number of Roma is increased for funding purposes on the basis of incorrect census figures, the same should be done with all communities in a similar situation. Conversely, if the census results are used as the only objective figures instead of unreliable estimates for the other communities, the same approach could be used for the Roma as well.

Despite the above objections, the differential treatment of Roma can be perhaps explained with the argument that the share of Roma underreported on the censuses is higher than the share of other minorities. Whether this is true remains doubtful in the absence of reliable estimates, but it would justify the preference given to Roma only. However, even in this case the figures from the Roma Atlas should not have been used as a benchmark. A different estimate for the specific purpose of participating in Roma cultural life should have been created by the legislators.

Since the law was not able to establish an exact method of determining the size of communities for funding purposes, it was also not able to design a mechanism for reallocating the shares of communities when

\footnotetext{
8059.6 per cent was specified in the first five drafts; see Draft law No. 5 from 17 October 2016, $\$ 23$.

${ }^{81}$ Law on the Fund to support the culture of national minorities, supra note 25, §22(1).

82 Draft law No. 5 from 17 October 2016, \$23.

${ }^{83}$ Law on the Fund to support the culture of national minorities, supra note 25, §22(1).

${ }^{84}$ Explanatory report, Specific part, supra note 79, p. 7.

85 Atlas of Roma communities in Slovakia 2013, UNDP (2014).

${ }^{86}$ Ibid., pp. 6-7.
} 
new census results became available. If the proportion of communities significantly changes, the law needs to be amended, which again leads to uncertainty in the absence of a clear method. It would have been more satisfactory to establish a clear methodology for determining the size of the communities and design a mechanism for automatically adjusting the shares in light of future censuses.

\section{Who Makes the Decisions?}

A positive feature of the 2017 Law is that the expert councils of minority communities are making final, binding decisions on funding individual projects. ${ }^{87}$ The Fund's director does not have discretionary powers to change or set aside their decisions. ${ }^{88}$ This is a welcome change from past practice, when similar expert committees' decisions were only treated as recommendations and frequently changed by political figures overseeing the funding of minority cultures. ${ }^{89}$ It should be mentioned that earlier drafts of the 2017 Law also gave expert councils only the power to make recommendations to the Fund's director, who was making all final decisions. ${ }^{90}$ This was changed due to the frequently raised suggestions of the minority communities. ${ }^{91}$

\section{How Are Decision-Makers Elected?}

The law is less satisfactory when it comes to selecting members of the expert councils, the Fund's main decision-making bodies. The councils have five members, "over half" of whom are elected by the minority communities, the rest being appointed by the Fund's director. ${ }^{92}$ The director is appointed by the Minister of Culture. ${ }^{93}$ In practice, three members of the councils are elected by the communities and two are political appointees.

The law or the explanatory report gives no reason as to why only three members of the councils are elected. ${ }^{94}$ While the director might have a legitimate interest in balancing the council's composition, for example, to give equal weight to different geographical regions or artistic professions, the law specifies no such criteria. The director has very wide discretion in whom to appoint. Despite proposals to the contrary, ${ }^{95}$ the law does not even establish that members of the councils must belong to or must be experts of the culture of the respective minority on whose council they sit. ${ }^{96}$

The chosen system gives a lot of weight to the director and indirectly the Minister of Culture to influence the composition of the expert councils and consequently their decisions. While currently the system is not abused and the appointed members are all experts from the relevant communities, the law does not prevent any future political appointees from becoming members of the councils. The appointment procedure is therefore one of the major weaknesses of the law, undermining its effectiveness.

The elected members are also not elected by the communities at large. Slovakia has no general law on minorities, defining the communities and establishing special voting registers. Nor were such electoral lists

\footnotetext{
${ }^{87}$ Law on the Fund to support the culture of national minorities, supra note $25, \S 7(1)$.

${ }^{88}$ Ibid., §15(7).

89 “A SZMK Koordinációs Bizottságának állásfoglalása a kormányhivatal 2011-es évi nemzeti kisebbségek kultúrájának támogatásával kapcsolatban és Juhász László válasza” (Position of the Coordination Committee of the RHS on the Government's Office support to minority cultures in 2011 and the response of László Juhász), Press release of the Roundtable of Hungarians in Slovakia, 16 July 2011.

90 Draft law No. 5 from 17 October 2016, §4(2).

91 Comments of the Hungarian community, supra note 76, p. 2.

${ }^{92}$ Law on the Fund to support the culture of national minorities, supra note 25, §7(6).

93 Ibid, §4(5).

94 Explanatory report, Specific part, supra note 79, p. 2.

95 Comments of the Hungarian community, supra note 76, 4.

${ }^{96}$ Law on the Fund to support the culture of national minorities, supra note 25, §8(1).
} 
proposed for the purposes of the 2017 Law. The members are therefore elected by cultural organizations of the respective minority communities. ${ }^{97}$ This approach has its tradition in Slovakia and is considered to work reasonably well. It stresses the professional features of the decision-making process over the populist ones. Nevertheless, it risks losing the involvement of communities at large in the discussion about cultural policy, turning it instead into an expert discussion.

\section{What is the Substantive Basis for Decisions?}

The Law on the Fund to Support the Culture of National Minorities does not specify any substantive criteria for supporting cultural activities. ${ }^{98}$ The Fund itself and the minority communities' expert councils can adopt documents specifying their internal rules, but it is not an obligation. ${ }^{99}$ In the absence of clear criteria, it is up to the discretion of expert councils and their members to evaluate the worthiness of each individual funding application subjectively. While their expertise is useful in this task, it is not a substitute for public cultural policy. Experts will have to make difficult decisions, evaluating proposals from different disciplines. Whatever criteria they might use to compare proposals from different regions, disciplines, and municipalities with different sizes and proportions of minority communities, these should be discussed publicly. This would ensure that the minority community can affect the development of its culture by setting priorities, by changing the weight of different criteria. Whether the community values printed newspapers over websites, a larger number of amateur theatres over a few professional ones, scattered small local cultural festivals over a few national or regional ones, or the other way round, it can only make a decision if the criteria are public. If they are not, the decision will be made by a few select experts in a haphazard and often arbitrary way. Public criteria also ensure that applicants for funds know in advance what to expect, what kind of activities they should develop.

The substantive funding criteria form the core of the community's cultural policy by setting the priorities of cultural development. As discussed above, presumably any organization or expert can draw up such a document, but no one has done so in Slovakia, not even members of the largest, the Hungarian community. Although attempts have been made, this is a serious piece of work, which requires a lot of resources and much consultation so that the final document reflects the views and is acceptable to all the community's relevant stakeholders. No private organization in itself is in a position to create such a document.

During the drafting of the bill it was proposed that the Fund, and respectively the individual expert committees, should be obliged to prepare public cultural policy documents for each minority community. ${ }^{100}$ The Fund certainly has the credibility and the resources for such a task; therefore, it could have overcome the collective action problem for all communities. However, this proposal was not accepted. The law as accepted does not require the adoption of public funding criteria. As a result, the funding decisions can only remotely and imperfectly reflect the communities' actual preferences.

One example which highlights the importance of minority cultural policy documents involves the definition of minority cultures. In the previous part it was argued that in the circumstances of Slovakia it is not difficult to separate cultures of respective communities from each other. However, it can be much more complicated to define which parts of a community's culture are performed in Slovakia, for example, which parts are genuinely connected to Hungarians in Slovakia compared to Hungarians living elsewhere. Hungarians

\footnotetext{
${ }^{97}$ Ibid., §7(9).

98 Ibid., $\$ 7(1)$.

99 Ibid., \$7(3) and §13(1).

100 Comments of the Hungarian community, supra note 76, p. 5.
} 
in Slovakia are part of a larger cultural market that transcends borders. Should Slovak funds be used to support the publications of Hungarian writers from Slovakia, to publish books which are then sold in Hungary? Should the Slovak system support the publication of books by Hungarian authors from Hungary to be published by publishers in Slovakia and then partly sold in Hungary? What about dance, music and theatre performances? In some cases, it is very hard to separate Hungarian culture in Slovakia from Hungarian culture in general. Nevertheless, the expert councils must know which activities can be supported and which cannot be. The Act does not define what approach should be used. Whether this should cover activities outside Slovakia, and which ones, is left to the decision of the expert councils. In the absence of a public cultural policy reflecting the wishes of the community about what should be supported from Slovak public funds, it is left to the individual preferences of members of the expert councils to back activities as they see fit.

\section{Legislative Guarantees}

The Law on the Fund to Support the Culture of National Minorities represents a major improvement from the perspective of legal guarantees. Until its adoption, no law regulated the funds allocated to the support of minority cultures. All such decisions were at the discretion of the government and were made annually.

On the other hand, cultural autonomy still lacks a constitutional guarantee. The adopted law can be modified or even repealed by any future parliamentary majority.

\section{Accommodating the Minority Communities' Needs}

The Law on the Fund to Support the Culture of National Minorities only deals with minority-specific aspects of the financing of culture. The law is implemented in the legislative framework concerning state support that was developed for the majority communities. ${ }^{101}$ In some respects, the general framework was not sufficiently modified to meet the needs of minority communities.

One problem lies in the short-term nature of grants and the costs that can be covered from them. The general legislative framework does not permit multi-annual funding schemes, nor does it allow covering administrative and other institutional fixed costs. ${ }^{102}$ It is thus not appropriate for maintaining larger, professional organizations, which require long-term financial stability and support for their professional administrative staff. For the majority community, such funding is available outside the cultural grant scheme: larger national organizations, such as folk ensembles, theatres, or national broadcasting are financed separately, under separate rules. The minority communities have very few such separately financed organizations. ${ }^{103}$ Their professional organizations are thus relying on the minority culture grant scheme, which is not appropriate for their needs.

An earlier proposal prepared in 2011 aimed to solve this problem by allowing the accreditation of professional organizations, which would lead to covering administrative costs in a multi-annual framework for the selected organizations. ${ }^{104}$ Although similar proposals were presented in the discussions in $2017,{ }^{105}$ they were not adopted in the law's final version. Minority cultural organizations must therefore operate in a funding

101 Law No. 524/2010 Col. 1. on providing grants in the competence of the Government Office of the Slovak Republic, 8 December 2010.

102 Ibid., §2(1).

103 Although they do have some, such as the Ifjú Szívek folk ensemble, the Danubian Museum and the theatres financed from budgets of regional governments.

104 Legislative proposal from 2011 on the protection and support of preservation and development of the culture of national minorities, supra note $39, \S 26(1)$.

105 Comments of the Hungarian community, supra note $76,7$. 
framework which does not meet their needs and which represents an obstacle to the professionalization and development of cultural organizations.

The 2017 Law adopted an interesting expansion of the supported activities compared to the general framework. In addition to all the usual activities found in the law on the mainstream cultural grants, the minority Fund also allows for the support of activities developing the use of minority languages. ${ }^{106}$ The majority community does not need such specific grants, as the majority language is supported in the relevant sense by all mainstream state institutions, which use, develop and give preference to the Slovak language as the state language, in accordance with the State Language Act. On the other hand, while minority languages can be used in some specific instances, there is no support provided to prospective users in terms of information about when and where minority languages can be used, translations of specific documents and terms, etc. These must be supplied by civil society, but at least the 2017 Law allows for the costs of such activities to be covered from the Fund on minority culture.

The 2017 Law also does not bring new changes or competences in the area of linguistic rights. The general legal regime, regulated mainly by the State Language Act and the Act on the Use of Minority Languages, remains unmodified. The Fund or its expert councils have no power to make rules about language use even internally. Several proposals were made during the legislative debate that would have allowed the fund to advertise its activities and calls for proposals in the respective minority languages, and the acceptance of applications and documents in these languages, but they were not adopted by the legislators. ${ }^{107}$ Ironically, the Fund, the minority cultural autonomy's main institution, will communicate with the minority communities and their cultural organizations in the state language only.

\section{Transparency}

In the past, support for minority culture in Slovakia was frequently criticized for corruption and nepotism. To ensure accountability and to gain the public's confidence, it was proposed during the discussions on the draft bill that all major steps in the funding allocation process be public: The criteria for evaluation of the applications, the expert councils' decisions and their reasoning, the individual grant contracts, and each project's final financial and narrative report would be accessible online. ${ }^{108}$ An early draft indeed included such a provision concerning transparency. ${ }^{109}$ However, for unknown reasons this provision was not adopted in the final law. The legislators only explained that the general rules on transparency would apply to the Fund as well. However, those only require the publicity of grant contracts, not of each individual decision and the final reports. It is hard to see any legitimate reason in limiting public accountability in this way. Given the difficult history of support for minority cultures, the lack of transparency could undermine public trust in the institution before it can properly start to operate.

\section{Involvement of the Community at Large}

The 2017 Law does not contain any obligations concerning consulting the respective communities at large about the funding scheme, its improvement, or the priorities of cultural policy. While such consultation might happen, it lacks a legislative guarantee. This is unfortunate in light of the obstacles of wider consultation: There

\footnotetext{
${ }^{106}$ Law on the Fund to support the culture of national minorities, supra note 25, §15(1)m).

107 Comments of the Hungarian community, supra note 76, 3.

108 Ibid., p. 8.

109 Draft law No. 4 from 5 August 2016, §23.
} 
is probably no stakeholder who would be opposed to it in principle; however, organizing consultation is workand resource- intensive, especially in the case of larger minorities. The same collective action problem, explained above, applies to the consultation process as well: While every (or most) member(s) of the community would be in favour of such consultation and would benefit from it, no one is willing to sacrifice themselves to organize it for the benefit of the others. It is the Fund which has the necessary capacity and financial resources to take action to break this deadlock. It also has the motivation: consultation primarily improves the expert councils' work and credibility. But at the same time the Fund is less likely to dedicate resources to this activity if it does not have an obligation to do so.

Experience to date is not promising. Minority communities were involved in the discussion of the draft bill, but they received no support, were often asked for their opinion with very short deadlines, and their proposals were often rejected without any explanation. ${ }^{110}$ The practice of stakeholder involvement certainly needs to improve and the adopted law could have done more to promote a culture of inclusion.

\section{Concluding Evaluation of the 2017 Law}

As the above analysis suggests, the 2017 Slovak Law on the Fund to Support the Culture of National Minorities is far from ideal. On the positive side, it provides for long-needed legislative guarantees for a minimal support to minority culture and its allocation among the communities, and allows the respective expert committees to make final decisions. On the other hand, it evades the difficult question of tying support for minority culture to the support provided for the majority culture, the allocation among communities is questionable and will have to be renegotiated after the next census, and the composition of the expert committees can be unduly influenced by the unfettered discretion of the Fund's director to nominate two of their members. Most importantly, the Fund lacks the necessary transparency rules and it is not required to make decisions under public substantive criteria negotiated and adopted with the involvement of the respective communities, reflecting their priorities.

While many of these deficiencies could theoretically be overcome by the Fund's actual practice, adopting a law which would make it an obligation is a missed opportunity. The most positive feature of the Fund is that it started to operate, and it represents an improvement compared to the heated political arguments of previous years. As the Fund develops its best and not so good practices, it will be in order in a few years to revise the Law to steer the system in the required direction.

\section{Evaluating the International Standards}

The above analysis shows what criteria can be used to measure the effectiveness of participation of minorities in decision-making relating to their cultural life. They can be used for comparative purposes, evaluating the effectiveness of different models; and they can also serve as a basis of international oversight of approaches adopted on the national level. Only a certain quality of decision-making can be characterised as autonomy. However, the label is of little importance: regardless of what it is called, effective participation is a right guaranteed by the Framework Convention. It is in the power of the Advisory Committee to review whether state parties to the Convention meet these or similar criteria.

\footnotetext{
${ }^{110}$ Interview with K. Sz., representative of the Hungarian community in the working group commenting on the legislative proposal, 18 March 2018.
} 
The criteria described here are much more detailed than the ones currently used by the Advisory Committee. In fact, the Advisory Committee gave very wide discretion to Slovakia in financing minority cultures, which is in line with its general approach. The Committee's approach is ineffective in terms of operationalizing its basic principles related to effective participation: as shown above, the Slovak system is far from effective, yet the Committee found little deficiencies with it. While states enjoy a certain margin of appreciation in implementing the right to effective participation (Weller, 2004), such a wide discretion serves no useful purpose. It legitimizes inefficient mechanisms and allows states to undermine the Framework Convention's guarantees. It also runs the risk of the Framework Convention becoming irrelevant. In fact, the Convention played no role in adopting the 2017 Law in Slovakia. Adoption of the law was dropped as a requirement in the last monitoring cycle by the Advisory Committee, and the Law does not reference the Framework Convention even in a tokenistic way.

The Advisory Committee formulated some useful principles for implementing the right to effective participation. The criteria proposed in this article are in line with these principles; they are operationalizing them in practice. Adopting them or similar ones as its own would allow the Advisory Committee to review the implementation of the right to participate in decision-making. In the absence of detailed standards, the principles will be of little relevance. If the country takes some steps to guarantee effective participation and the minorities are still dissatisfied with the result, it will be impossible for the Advisory Committee to say whether the Framework Convention's requirements were met. General principles only allow a limited form of oversight. In the absence of detailed standards, their operationalization is left to the discretion of the state, abandoning the possibility of meaningful international oversight.

For that reason, this article argues that the Advisory Committee should develop more detailed standards concerning what the development of minority culture and the participation of minority communities in this process requires. Otherwise, the Framework Convention will become an empty promise, one which is of little use to minority communities.

\section{Conclusion}

This article argues that the main question relating to cultural autonomy is not whether it exists or not, but of what quality it is. It is still a meaningful approach to define a threshold point at which the autonomy begins to exist, but that threshold is not so clear and is also of little importance. It is not so clear because autonomy, as shown above, is a multi-dimensional phenomenon. Simplifying its existence to a yes/no inquiry would not do justice to situations where some features are highly developed, while others are unsatisfactory. It is also of little importance because a minority community can hardly be satisfied with an autonomy that barely exists. The more important question is: What is the quality of the given model and in which ways could it be improved to reach a desired level?

This article proposed that a right to cultural autonomy already exists in international law, although not by that name. Autonomy can be characterised as a decision-making mechanism, allowing the minority community to make decisions regarding its cultural life in a manner similar to the way the majority does through the general political process. Autonomy is one form, a developed form of the right of communities and its members to effectively participate in decisions regarding their cultural life, protected by Articles 15 and 5 of the Framework Convention on National Minorities. 
Taking the international requirements on effective participation as the starting point, the article proposed criteria that can serve to measure the implementation of these principles. They can ensure effective implementation by states and oversight by international bodies. These criteria simultaneously address two questions, concerning how to ensure the effective participation of minorities in decision-making affecting their cultural life and how to design an effective system of cultural autonomy for minorities. These two questions have the same answers, because these two institutions in fact overlap, the latter is a developed form of the former.

\section{References}

Dinstein, Y. (2011). Autonomy regimes and international law. Villanova Law Review, 56, 437-438.

Fiala-Butora, J. (2016). Hungarians in Slovakia and the evolution of Hungarian-Slovakian bilateral relations-Improvement or stalemate? European Yearbook of Minority Issues, 12, 161.

Ghai, Y. (Ed.). (2000). Autonomy and ethnicity: Negotiating competing claims. Cambridge: Cambridge University Press.

Hannum, H. (1990). Autonomy, sovereignty, and self-determination: The accommodation of conflicting rights. Philadelphia: University of Pennsylvania Press.

Lapidoth, R. (1997). Autonomy: Flexible solutions to intrastate conflict. Washington, D.C.: United States Institute of Peace.

LégaréA., \& Suksi, M. (2008). Rethinking the forms of autonomy at the dawn of the 21 st century. International Journal on Minority and Group Rights, 15, 143-155.

Palermo, F. (2010). The dual meaning of participation: The advisory committee's commentary to Article 15 of the FCNM. European Yearbook of Minority Issues 2007/2008, 7, 409-424.

Pap, A. L. (2015). Racial, ethnic, or national minority? Legal Discourses and policy frameworks on the Roma in Hungary and beyond. Social Inclusion, 3(5), 32-47.

Petőcz, K. (2010). Participation of national minorities in decision-making in Slovakia. European Yearbook of Minority Issues 2007/2008, 7, 752.

Ravasz, Á. (2012). Szlovákiai magyarok és a 2011-es népszámlálás: Mérleg és elemzés (Hungarians in Slovakia and the 2011 census: Balance and analysis). Komárno: Kempelen Institute.

Shaw, M. N. (1997). Peoples, territorialism and boundaries. European Journal of International Law, 3, 478-507.

Suksi, M. (2008). Personal autonomy as institutional form-Focus on Europe against the background of Article 27 of the ICCPR. International Journal on Minority and Group Rights, 15, 177.

Suksi, M. (Ed.). (1998). Autonomy: Applications and implications. The Hague: Kluwer Law International.

Tkacik, M. (2008). Characteristics of forms of autonomy. International Journal on Minority and Group Rights, 15, 369-401.

Torode, N. (2008). National cultural autonomy in the Russian federation: Implementation and impact. International Journal on Minority and Group Rights, 15, 163-180.

Vacca, A. (2010). A comparative approach between the council of Europe treaties and the European Union framework in the legal protection of minority languages. Revista de Llengua i Dret, 53(111), 115.

Verstichel, A. (2009). Participation, representation and identity. The right of persons belonging to minorities to effective participation in public affairs: Content, justification and limits. Intersentia: Antwerp.

Verstichel, A. (2010). Representation and identity: The right of persons belonging to minorities to effective participation in public affairs. European Yearbook of Minority Issues 2007/2008, 7, 452.

Weller, M. (2004). Creating the conditions necessary for the effective participation of persons belonging to national minorities. International Journal on Minority and Group Rights, 10, 265-290.

Weller, M. (2010). Minority consultative mechanisms: Towards best practices. European Yearbook of Minority Issues 2007/2008, $7,425-447$.

Yupsanis, A. (2016). Cultural autonomy for minorities in the Baltic States, Ukraine, and the Russian federation: A dead letter. Polish Yearbook of International Law, 36, 110. 